\title{
Influence of Detasseling Methods on Seed Yield of Some Parent Inbred Lines of Turda Maize Hybrids
}

\author{
Alexandru Bogdan Ghețe ${ }^{1}$, Voichița Haș ${ }^{2, *}$, Roxana Vidican ${ }^{1, *}$, Ana Copândean ${ }^{2}$, \\ Ovidiu Ranta ${ }^{1}$, Cristina Maria Moldovan ${ }^{1}$, Ioana Crișan ${ }^{1}$ (D) and Marcel Matei Duda ${ }^{1}$ (D) \\ 1 Faculty of Agriculture, University of Agricultural Sciences and Veterinary Medicine, Manastur Street 3-5, \\ 400372 Cluj-Napoca, Romania; alexandru.ghete@usamvcluj.ro (A.B.G.); ovidiu.ranta@usamvcluj.ro (O.R.); \\ cristina.moldovan@usamvcluj.ro (C.M.M.); ioana.crisan@usamvcluj.ro (I.C.); \\ marcel.duda@usamvcluj.ro (M.M.D.) \\ 2 Agricultural Research and Development Station (ARDS), Agriculturii Street 27, 401100 Turda, Romania; \\ copandean_ana@yahoo.com \\ * Correspondence: hasvoichita@yahoo.com (V.H.); roxana.vidican@usamvcluj.ro (R.V.); \\ Tel.: +40-264-596-384 (R.V.)
}

Received: 8 April 2020; Accepted: 15 May 2020; Published: 19 May 2020

\begin{abstract}
During the process of maize seed production, in order to ensure the genetic purity of parental forms of hybrid maize, an important work performed is the removal of male inflorescences from plants on mother rows. Hand detasseling has high precision but is labor-intensive. Mechanical detasseling offers the possibility to cover large acreages in a short period of time, but the number of leaves removed has a varying influence on plant performance and seed yield. The aim of this study was to simulate three types of damages on plants similar to those induced through mechanical detasseling and to assess the effects for five inbred lines during the course of three years. Results show that when tassels alone were removed, the average seed yield decreased an average of $4-21 \%$. When two leaves were removed with the tassel, yield decreased an average of $22-31 \%$, while when plants were cut above the main ear, seed yield decreased an average of 31-66\%. Environmental conditions influenced seed yield, especially high temperatures during flowering. Yield response to tassel and leaves removal varied between the inbred lines. Genotype controls maize ear and kernel characters, while environmental factors exercise a strong influence on seed yield, due to the succession of years with contrasting weather conditions in a key phenophase. Within the trend of full mechanization in agriculture, identification of inbred lines that cope better with plant damage can assist in optimizing seed production.
\end{abstract}

Keywords: character; pollen; ear; kernel; cob; genotype; technology; environment; breeding

\section{Introduction}

Zea mays L. is one of the most cultivated cereal crops in the world. It is used in the human diet, as animal feed, and to the obtaining of many other industrial products [1-4]. In Romania, maize was brought about 300 years ago and gradually replaced old millet plantations until becoming a staple food [2]. According to the Ministry of Agriculture and Rural Development of Romania, in less than 10 years after joining the European Union (EU), national maize production doubled [5]. Today, Romania is recognized as the largest maize grower within the EU [6,7]. Because domestic maize requirements are only around 5 million tons while production exceeds 10 million tones, there is significant export potential [7]. To capitalize on this opportunity, maize breeders face the complex challenge to increase the cost efficiency of maize seed production, minimize seed losses, and ensure an increasing supply of high-quality seed. Currently, at the national level, breeding efforts and testing 
of new maize genotypes are conducted by research stations, growers' associations and companies established in different regions of the country [8]. Important maize germplasm collections used in breeding programs can be found at several research stations across Romania, such as the Agricultural Research and Development Station from Turda (ARDS) [9].

In the last six decades, most commercial maize crops use hybrid seed created based on inbred lines which are obtained through successive generations of self-pollination and artificial selection [10-16]. Given current importance maize has in Romania, optimization of the seed production process is incredibly important. To achieve this, besides specific technical measures meant to ensure the genetic purity of inbred lines [17-19], it is also important to study the behavior of inbred lines under different aspects and adapt seed production technology to their needs. During the seed production process based on male-fertile parental forms, the most important work performed is the detasseling of maize lots, which consists of removing tassels-the male maize inflorescences-from all plants on mother rows before shedding pollen. The degree of accuracy of detasseling directly influences the quality of seed obtained $[17,20,21]$. Through mechanical detasseling, costs can be reduced by about $30 \%$, compared to manual detasseling [10]. However, the mechanical action of the detasseler that pulls tassels also damages the plant and leaves to varying degrees [20,22]. Due to the importance detasseling has in obtaining maize seed, there is a high interest in studying the influence of detasseling on corn performance, with a focus on mature grain yield [23]. This research is meant to bring a contribution to the understanding of factors affecting seed yield of maize inbred lines under the continental climate of Transylvania, with the purpose to identify possibilities to optimize certain stages of seed production.

The aim of this study was to assess the influence of different detasseling methods on the quantity and quality of seed yield, ear, and kernel characters for some inbred lines in pedo-climatic conditions of ARDS Turda, Romania during 2015-2017. Two objectives were defined:

- evaluation of genotype response to three different plant damages, (similar to those induced by mechanical detasseling) in relation to several quantitative and qualitative traits;

- identification of efficiency and suitability of this practice for tested inbred lines and make recommendations based on the link identified between experimental years, genotype, and detasseling method in local conditions.

\section{Materials and Methods}

The experiment was established at the Agricultural Research and Development Station (ARDS) from Turda, Romania, located at $46^{\circ} 34^{\prime} 50.5^{\prime \prime} \mathrm{N} 23^{\circ} 47^{\prime} 16.4^{\prime \prime} \mathrm{E}$ and took place between 2015-2017. Climate is temperate continental [24]. The field had clay-loam soil type, with good nitrogen, phosphorus, potassium and micronutrient content, as well as an average humus level. Topsoil had neutral $\mathrm{pH}$ [25]. Temperatures and precipitation levels during the experimental period are presented in Figure 1a,b.

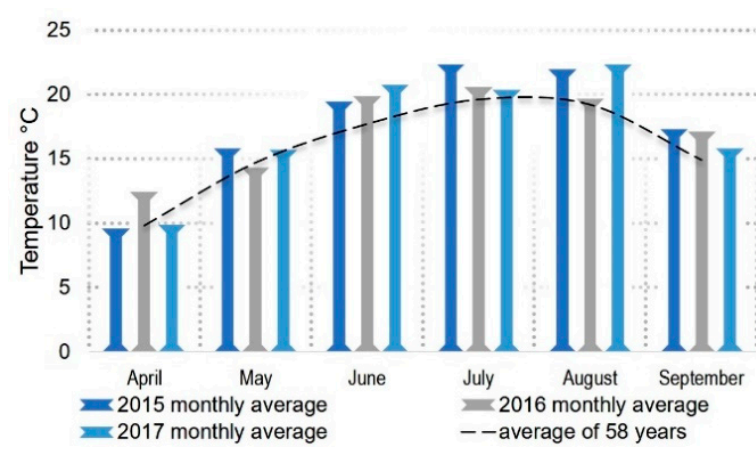

(a)

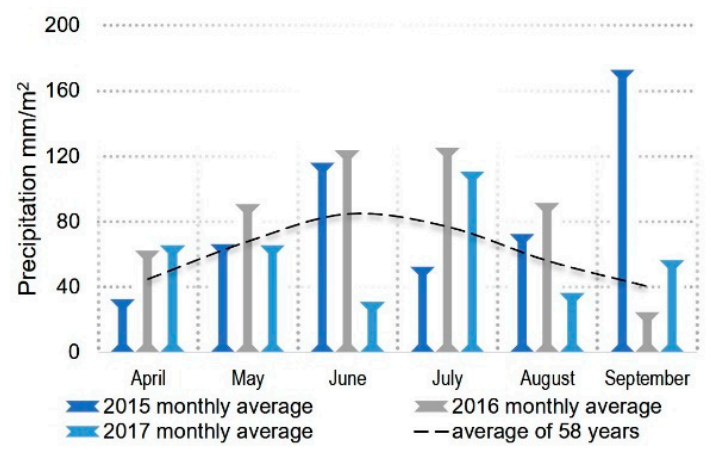

(b)

Figure 1. Climatic conditions during experimental years: (a) temperature, (b) precipitation levels, according to weather station from Agricultural Research and Development Station (ARDS) Turda. 
In the first year of the experiment, during maize growing season: 28 April-24 September 2015 , occurred episodes of low precipitation levels during sowing and sprouting as well as during flowering and grain filling phenophases (July) in addition to high temperatures registered over summer, these caused poor pollination resulting in barren ear tips, low filling ability, and fast loss of kernel moisture. The second experimental year: 27 April-29 September 2016, presented optimal conditions for this crop, temperature and precipitation levels during sowing and sprouting ensured uniformity of seedlings. During the third experimental year: 4 May-25 September 2017, weather conditions were favorable for maize development although the lowest monthly average precipitation levels registered during the experiment occurred in June 2017. During the experiment, summer months registered higher monthly average temperatures compared to the average temperature for the last 58 years. Precipitation levels were below the multiannual average for June 2017 and July 2015 (Figure 1a,b).

The experimental trial consisted of the interaction of three factors: [years (3) $\times$ treatments (4) $\times$ lines (5) $] \times$ two replicates, corresponding to 120 experimental plots under conventional cultivation. The cultivated surface had $1172 \mathrm{~m}^{2}$. The biologic material was represented by five inbred lines $(\mathrm{L})$ : TC 344, TA 426, TC 385A, TA 447, and TA 452. These have been used as the mother parent for the latest hybrids created at ARDS Turda. Treatments consisted of four detasseling methods (D) applied to plants: D1-control/no detasseling, D2-tassel alone removed, D3-tassel plus 2 leaves removed, D4-all leaves above the ear were removed. Maize density was 50,000 plants/ha. Plants were openly pollinated.

Biometric determinations at harvest were:

- $\quad$ seed yield ( $\mathrm{kg} / \mathrm{ha})$;

- $\quad$ ear weight $(\mathrm{g})$, ear length and diameter $(\mathrm{cm})$, kernels weight/ear $(\mathrm{g})$;

- $\quad$ cob diameter $(\mathrm{cm})$, number of rows/ear, number of kernels/row;

- $\quad$ kernel depth $(\mathrm{cm})$, thousands of kernels weight-TKW $(\mathrm{g})$, kernels dry matter $(\%)$.

For each variant, seed yield was determined at harvest on $7 \mathrm{~m}^{2} \times 2$ replicates, while for the other characters, were determined on 10 ears each $\times 2$ replicates in three consecutive years $(Y)$ : 2015-2017.

Statistical tests applied were analysis of variance (ANOVA) and the Fisher least significance difference test (LSD). Least significance values at $p$ levels $0.05,0.01$, and 0.001 for each character studied are provided in Table S1 from the Supplementary file, in addition, the standard deviation and standard error for key agronomic traits are found in Table S4.

\section{Results}

\subsection{Seed Yield}

Experimental factors, as well as their interaction, exercised significant influence on seed yield (Table S2, Supplementary file). But the strongest influence was exercised by experimental years followed by detasseling methods which together explain $60 \%$ of the overall variance. The inbred line alone explains only $12.7 \%$ of the overall variance for seed yield. Interactions between factors explain $24.9 \%$ of overall variance (Figure 2 ).

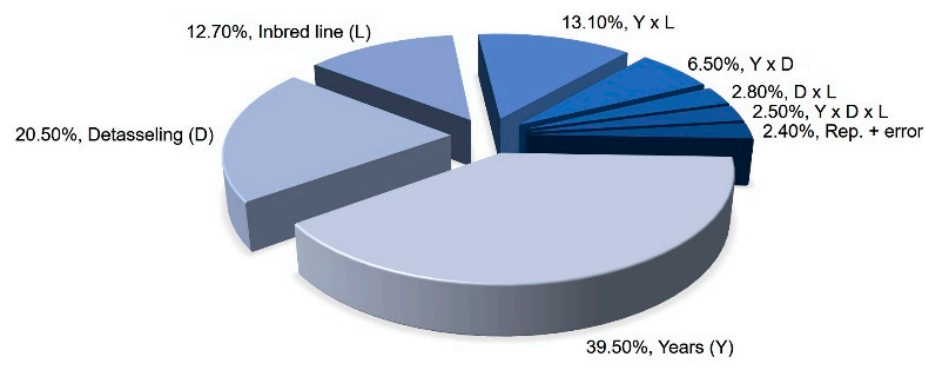

Figure 2. Share of factors and their interaction (\%) to overall variance $\left(\mathrm{s}^{2}\right)$ for maize seed yield during 2015-2017. 
All inbred lines registered a decrease of seed yield in response to the application of the three detasseling methods (Figure 3). The yield reduction for the five inbred lines averaged $4 \%$ for inbred line TA 426 and $21 \%$ for inbred line TC 344 when only the tassels were removed. When the tassel was removed together with two leaves, seed yield decreased by $22 \%$ for the line TA 452 and $31 \%$ for the line TC 344. In the case of removing all the leaves above the main ear, seed yield losses were highly significant compared to the control. Both lines TC 344 and TA 426 recorded a seed yield loss of $48 \%$ while the highest loss of seed yield was registered for TC 385A (66\%). The lowest seed yield decrease occurred for the lines TA 447 of only $31 \%$ followed by TA 452 with a decrease of $34 \%$. These two last lines have on average 4.4 and 4.5 leaves per plant above the main ear, respectively compared to the other three lines which present between 6.0-6.5 leaves per plant above the main ear. Thus, it was interesting to observe the lines that present a higher number of leaves above the main ear present also the highest seed yield losses following the detasseling method which produces major damage to plants by removing all leaves above the main ear (D4). At the same time, a line characterized by a lower number of leaves above the main ear (TA 447) recorded the lowest seed yield loss following removal of all leaves above the main ear. For the lines TC 344 and TC 385A, the seed yield losses were significant both in the case of the removal of tassels with two leaves $(21 \% ; 27 \%)$ and especially after removal of all leaves above the main year $(48 \%$; 66\%). Probably leaves left on the plant in the case of lines with a lower number of leaves per plant above the main ear, have a higher photosynthetic capacity. Yield responses to leaf removal varied between inbred lines. When tassels alone were removed (D2), a decrease of the seed yield was insignificant for two inbred lines: TA 426 and TA 452. For the other three inbred lines, the decrease in yield was significant, especially for TC 344 and TC 385A (Figure 3).

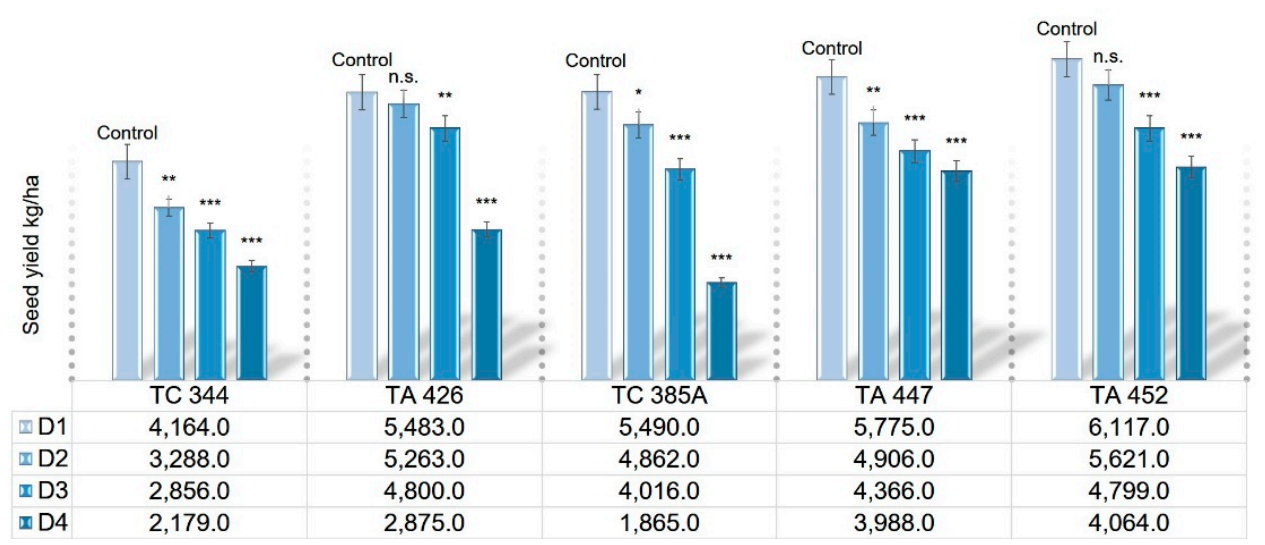

Figure 3. Combined effect of inbred line and detasseling method on maize seed yield ( $\mathrm{kg} / \mathrm{ha}) \mathrm{during}$ 2015-2017; D1-D4 detasseling methods; inbreds code names: TC 344, TA 426, TC 385A, TA 447, TA 452;

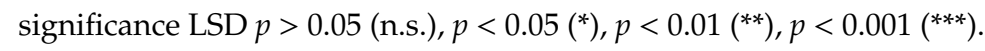

\subsection{Ear, Cob, and Kernel Traits}

Maize seed yield decrease was the result of a decrease of ear weight and length, kernels weight/ear, the number of kernels/row and number of rows/ear. All these traits were significantly influenced by detasseling $(D)$, genotype $(\mathrm{L})$, and their interaction $(\mathrm{D} \times \mathrm{L})$. Regarding the differences between inbred lines for analyzed characters, the highest ear weight and kernel weight were recorded by TA 426 and TA 447, the longest ear and the highest number of kernels/row for line TC 385A, and highest row number/ear for line TA 426 (Figures 4 and 5).

However, genotype had a higher influence on the ear characters except for the ear weight and kernels weight/ear, than detasseling. Additionally, triple interaction of the factors has a higher influence on the ear weight than on the ear length. A decrease in the number of kernels per row and ear length significantly influenced the yield differences between variants (Table S3, Supplementary file).

Ear traits varied highly between inbred lines in response to the removal of leaves. Removing all the leaves above the main ear (D4) had a negative effect on most of the ear's characters: ear weight 
and length, kernels weight/ear, and the number of kernels per row for the five lines (Figures 4 and 5). Removal of the tassel with two leaves resulted in a decrease of ear weight with 10-12\% relative to control and among the five genotypes analyzed, the inbred line TC 385A proved to be more sensitive (Figure 4).

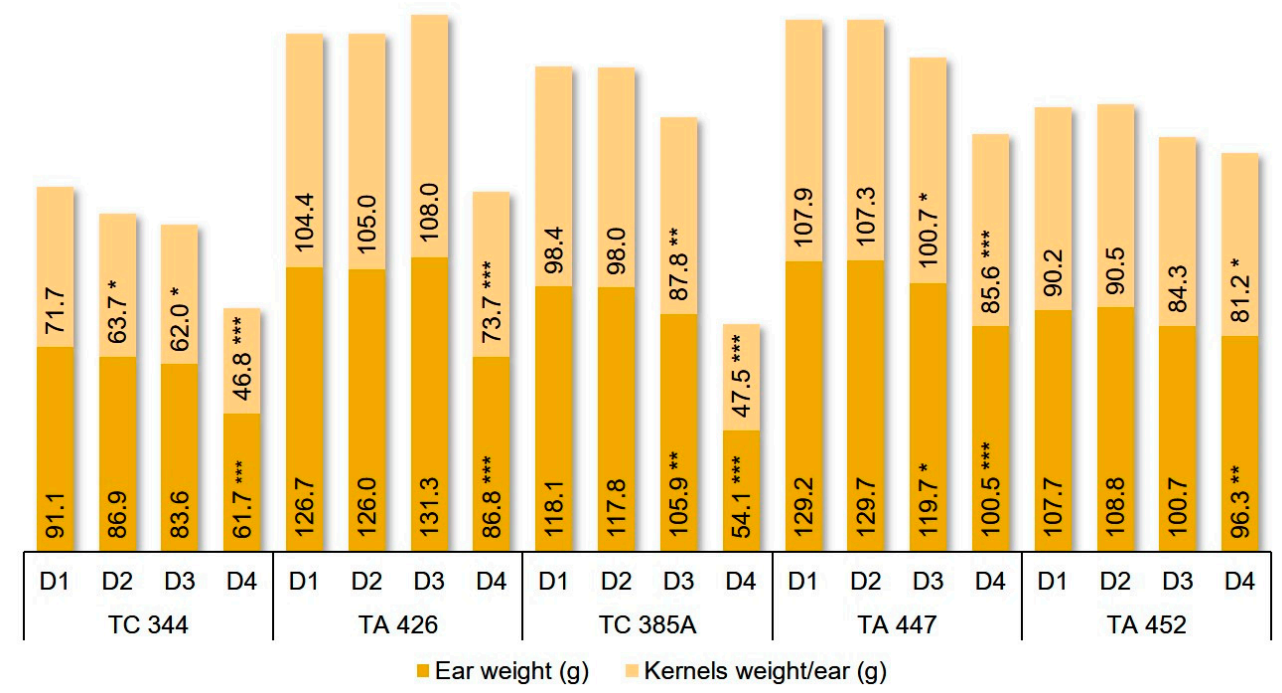

Figure 4. Combined effect of inbred line and detasseling method (D) on maize ear weight (g) and kernels weight/ear (g) during 2015-2017; significance LSD $\left.p<0.05\left(^{*}\right), p<0.01\left({ }^{* *}\right), p<0.001{ }^{* * *}\right)$.

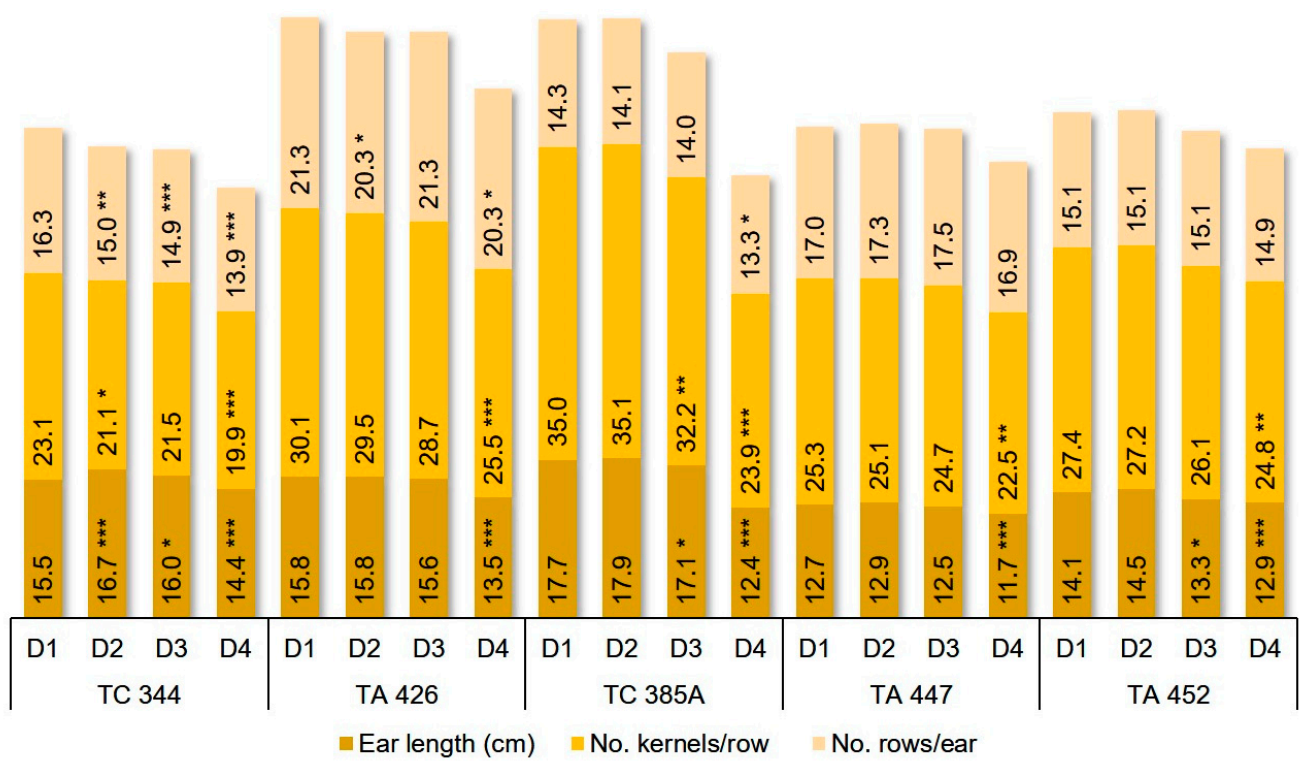

Figure 5. Combined effect of inbred line and detasseling method (D) on maize ear length (cm), number of kernels/row and number of rows/ear during 2015-2017; significance LSD $p<0.05\left({ }^{*}\right), p<0.01\left({ }^{* *}\right)$, $\left.p<0.001{ }^{* * *}\right)$.

The kernels weight/ear decreased with $10 \%$ for TA 452 , with $21 \%$ for TA 447 and with $52 \%$ for TC 385A (Figure 4). In the case of the other two detasseling methods, inbred lines behaved differently. All three detasseling methods (D2, D3, D4) resulted in a highly significant decrease in the number of rows/ear for line TC 344. Lines TA 447 and TA 452 presented no statistically significant response to either detasseling method for the number of rows/ear (Figure 5).

Inbred lines and detasseling methods significantly influenced all analyzed kernel traits (Table S3, Supplementary file). Detasseling and the interaction between detasseling and inbred line had a stronger influence on TKW (thousand-kernels weight) than on kernels dry matter and on kernel 
depth. Triple interaction $\mathrm{Y} \times \mathrm{D} \times \mathrm{L}$ had significant influence only on kernel depth and cob diameter. The experimental years did not influence significantly TKW (thousand-kernels weight) but exercised statistically significant influence on the other kernel traits (Table S3, Supplementary file). Out of the five inbred lines tested, only TA 452 experienced a significant decrease of kernel dry matter following D2 and D3 detasseling methods. The application of the D4 detasseling method caused a highly significant decrease of TKW for the line TC 385A (Figure 6).

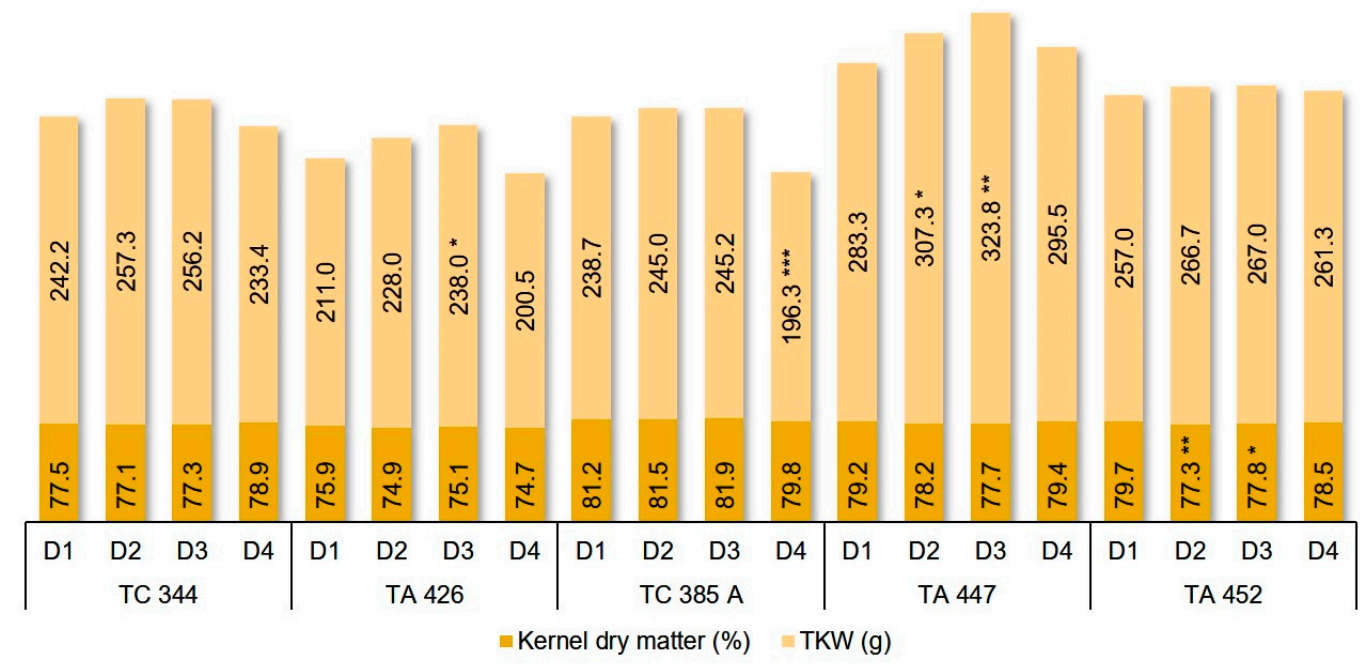

Figure 6. Combined effect of inbred line and detasseling method on kernel dry matter (\%) and thousand kernels weight (TKW g) during 2015-2017; significance LSD $p<0.05\left(^{*}\right), p<0.01\left({ }^{* *}\right), p<0.001\left(^{* * *}\right)$.

A significant decrease of ear diameter following detasseling was recorded by four out of five inbred lines and had no significant effect on one of them: TA 452. Detasseling exercised a significantly negative influence on cob diameter and kernel length for two inbred lines (Figure 7).

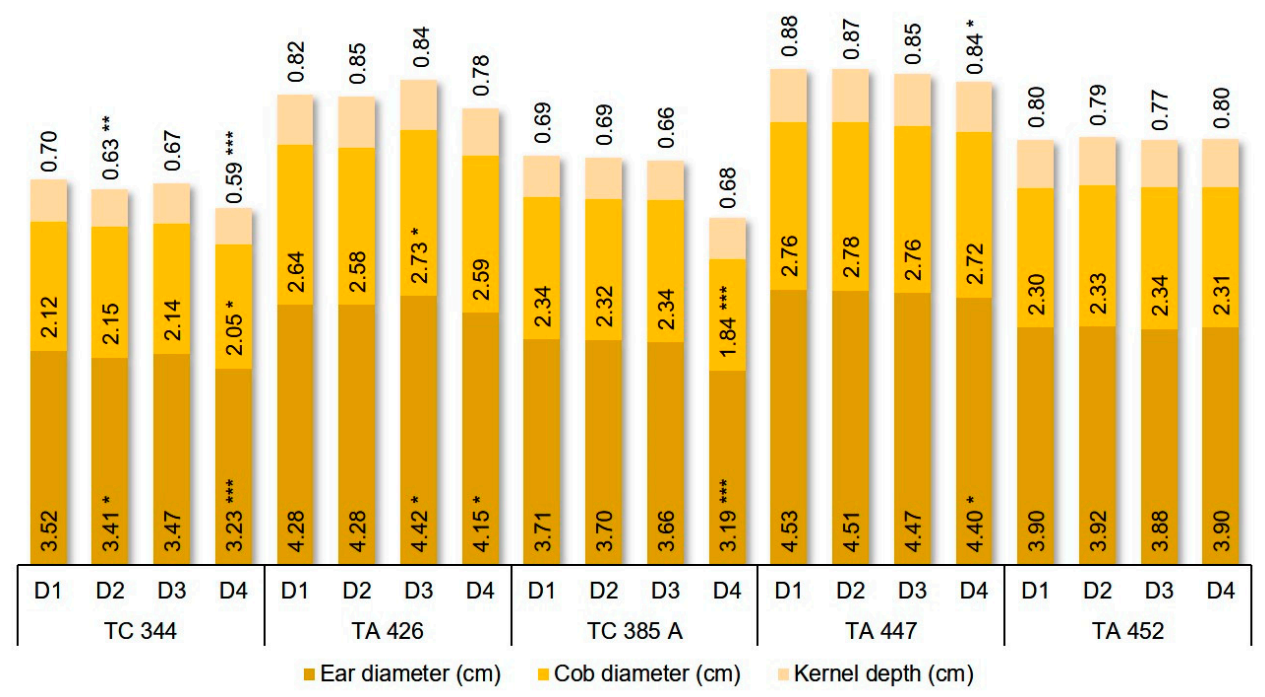

Figure 7. Combined effect of inbred line and detasseling (D) method on maize ear diameter (cm), cob diameter $(\mathrm{cm})$ and kernel depth $(\mathrm{cm})$ during 2015-2017; significance LSD $p<0.05\left({ }^{*}\right), p<0.01\left(^{* *}\right)$, $\left.p<0.001{ }^{* * *}\right)$.

\section{Discussion}

Maize yield and grain quality are the results of the interaction between genetic, environmental, and agronomic factors [11,26-28]. Overall, results are in accordance with previous studies which suggest that plant damage can have more or less serious consequences on seed yield, depending on 
both genotype and environmental conditions [23]. Not all genotypes are well suited for mechanical detasseling while most suitable ones are those that have a high degree of uniformity. Often, mechanical detasseling must be supplemented by hand detasseling to remove missed or late-maturing tassels.

The results of this study demonstrate that detasseling can cause seed yield losses in all inbred lines tested. By removing the tassels alone yield losses were between $4-21 \%$. Removal of all leaves above the main ear caused highly significant loss of seed yield, with a decrease between 31-66\%, while two out of five inbred lines (TA 447 and TA 452) produced about $4000 \mathrm{~kg} / \mathrm{ha}$ even after plants were cut above the main ear. Results suggest that seed quantity and quality can decrease significantly as a result of the reduction of the plant photosynthetic area. Because grain filling occurs mainly from photo-assimilates produced post-anthesis, it is understandable why the reduction of leaf area, particularly the removal of leaves above the main ear, which are considered the most photosynthetically active, can have negative consequences for maize grain yield and other grain traits [29] as reported in previous studies [29-32].

One study shows that for Pioneer 30F90 simple maize hybrid in conditions of Paraná, Brazil, removal of tassel together with 4-5 leaves caused a significant decrease in the number of grains per row [29]. Another study conducted in southern Brazil, in conditions from Minas Gerais, reports that maize hybrid NB7376 registered 20\% seed yield decrease and $8 \%$ TKW decrease following removal of all leaves above the main ear [30]. A study that compared the effects of five types of detasseling methods on two lines and one hybrid (CMS 355) concluded that manual detasseling or the use of male-sterile genotypes are better practices since whorl pull-off, as well as mechanical detasseling, negatively affects the seed production of maize plants [31]. Machine detasseling caused a $24.5 \%$ seed yield decrease in AG 122 hybrid Monsanto when the machine was programmed to remove $90 \%$ of the tassels with tires [32].

Because genotype exhibits different levels of phenotypic expression under the influence of environmental conditions, a large genotype by environment interaction can occur under stressful conditions [33]. This further explains why detasseling damage acting as abiotic stress for the plant causes high seed losses particularly in years less favorable for the development of this plant and why there is a variation of this seed decrease among inbred lines. Because some lines seem less affected compared to others following extensive plant damage, clearly there are genotypes more suitable for mechanical detasseling. Pin-pointing the underlying physiologic and molecular mechanisms and identifying an array of potential markers representative of the plant's ability to cope with the stress induced by damage caused to the plants could prove useful in screening existing maize germplasm collections for this type of tolerance. This becomes even more pressing due to the transition to full mechanization in agriculture and where identification of suitable inbred lines more tolerant to damage induced by mechanized detasseling can ultimately assist in the optimization of seed production. Similarly, other authors remark the lack of maize germplasm designated as suitable for full crop mechanization prompting the need for more research [34].

Besides genotype, climatic parameters such as water availability and temperature levels are recognized as key factors responsible for maize crop productivity $[26,27,29]$ and rainfall between April-August has a higher influence on maize yield than nitrogen fertilizer [8]. Particularly, maize is most sensitive to drought stress during pollination and grain-filling $[35,36]$. As noted in this study, under the influence of a continental climate, weather can act as a strong abiotic conditioning factor for maize seed yield. To reduce this effect, the precision of detasseling could be decided depending on environmental conditions in order to minimize plant damage and consequently seed losses in unfavorable years. Cost efficiency can be reached both by applying mechanical detasseling for lines that show lesser seed yield loss or by limiting manual detasseling only to valuable inbred lines that prove sensitive to plant damage caused by incorrect or fast mechanical detasseling. From the perspective of future maize breeding programs, results suggest that given the climatic particularities of Romania, maize genotype stability to environmental factors and adaptation to local conditions should become key performance criteria for maize genotypes. Due to the current climate trend at a global level, there is a particular need for enhancing maize tolerance to drought and heatwaves [37], especially since 
climatic models predict more frequent and severe extreme weather events with serious impact for cereal crops and implicitly for food security [38].

\section{Conclusions}

This research explored the relationship between genotype, climatic conditions, and detasseling method on seed yield of five inbred lines during a three-year simulation experiment, with the purpose to identify ways to optimize the maize seed production technology.

Results indicate that seed yield decreases directly proportional to the extensiveness of damage induced to plants. Maize genotype determines the response to detasseling, with inbred lines that present a higher number of leaves above the main ear as the genotype-trait experiencing the highest seed yield loss following extensive plant damage compared to inbred lines which present a lower number of leaves per plant above the main ear.

Continental climate conditions with fluctuations from one year to another can exercise strong influence over quantitative maize characters.

Supplementary Materials: The following are available online at http://www.mdpi.com/2073-4395/10/5/729/s1, Table S1. Least significance difference values for maize agronomic traits analyzed; Table S2. Influence of experimental factors on maize seed yield 2015-2017; Table S3. Influence of experimental factors on maize ear characters 2015-2017; Table S4. Standard deviation and standard error of mean values for key maize traits 2015-2017.

Author Contributions: Conceptualization, A.B.G., V.H. and M.M.D.; methodology, A.B.G., V.H. and M.M.D; validation, V.H.; formal analysis, A.B.G. and M.M.D.; investigation, A.B.G.; resources, V.H. and A.C.; writing —original draft preparation, A.B.G. and I.C.; writing—review and editing, R.V., V.H., A.C, O.R., and C.M.M.; supervision, V.H. and M.M.D. All authors have read and agree to the published version of the manuscript.

Funding: This research received no external funding.

Acknowledgments: Authors are thankful to all colleagues from maize breeding laboratory of ARDS Turda for their help with field work and for logistic support.

Conflicts of Interest: The authors declare no conflict of interest.

\section{References}

1. Ghețe, A.B.; Duda, M.M.; Vârban, D.I.; Vârban, R.; Moldovan, C.; Muntean, S. Maize (Zea mays), a prospective medicinal plant in Romania. Hop Med. Plant. 2018, 26, 44-51.

2. Popescu, A. Maize and wheat-Top agricultural products produced, exported and imported by Romania. Sci. Pap. Ser. Manag. Econ. Eng. Agric. Rural Dev. 2018, 18, 14.

3. Shiferaw, B.; Prasanna, B.M.; Hellin, J.; Bänziger, M. Crops that feed the world 6. Past successes and future challenges to the role played by maize in global food security. Food Sec. 2011, 3, 307. [CrossRef]

4. Babic, V.; Nikolic, A.; Andjelkovic, V.; Kovacevic, D.; Filipovic, M.; Vasic, V.; Mladenovic-Drinic, S. AUPOV morphological versus molecular markers for maize inbred lines variability determination. Chil. J. Agr. Res. 2016, 76, 417-426. [CrossRef]

5. Porumb-Ministerul Agriculturii si Dezvoltarii Rurale. Available online: https://www.madr.ro/culturi-decamp/cereale/porumb.html (accessed on 16 December 2019).

6. Sharp Contrasts between Maize Harvests in the EU after Heatwave. Reuters 2019. Available online: https://www.reuters.com/article/us-europe-maize/sharp-contrasts-between-maize-harvests-in-the-euafter-heatwave-idUSKCN1VX1Z2 (accessed on 16 December 2019).

7. Popescu, M.; Cristea, S.; Chiriac, A.R.; Teican, D. The evolution of maize production in Romania. In Agrarian Economy and Rural Development-Realities and Perspectives for Romania; The Research Institute for Agricultural Economy and Rural Development (ICEADR): Bucharest, Romania, 2018; pp. 132-136.

8. Halmajan, H.-V.; Sitaru, B.; Dosinescu, S.; Surca, E.; Petre, I. Maize yield evolution in Romania and farmers' involvement in increasing it. Sci. Pap. Ser. A Agron. 2017, 60, 270-274.

9. Istoric-Statiunea de Cercetare Dezvoltare Agricola Turda. Available online: https://scdaturda.ro/istoric (accessed on 16 December 2019). 
10. Ghețe, A.B. Cercetări Privind Perfecționarea Tehnologiei de Producerede Sămânță la Porumb. Ph.D. Thesis, University of Agricultural Sciences and Veterinary Medicine of Cluj-Napoca, Cluj-Napoca, Romania, 2019.

11. Ona, A.D.; Muntean, L.; Haș, V.V.; Varga, A. Combining ability for yield of single-cross hybrids derived from maize composites (Zea mays L.). Not. Bot. Hort. Agrobot. 2019, 47, 465-469. [CrossRef]

12. Șuteu, D.; Băcilă, I.; Haș, V.; Haș, I.; Miclăuș, M. Romanian maize (Zea mays) inbred lines as a source of genetic diversity in SE Europe, and their potential in future breeding efforts. PLoS ONE 2013, 8. [CrossRef]

13. Lee, M. Inbred lines of maize and their molecular markers. In The Maize Handbook; Freeling, M., Walbot, V., Eds.; Springer Lab Manuals; Springer: New York, NY, USA, 1994; pp. 423-432.

14. Yadav, V.K.; Singh, I.S. Comparative evaluation of maize inbred lines (Zea mays L.) according to dus testing using morphological, physiological and molecular markers. Agric. Sci. 2010, 1, 131-142. [CrossRef]

15. Liu, K.; Goodman, M.; Muse, S.; Smith, J.S.; Buckler, E.; Doebley, J. Genetic structure and diversity among maize inbred lines as inferred from DNA microsatellites. Genetics 2003, 165, 2117-2128.

16. Mikić, S.; Kondić-Špika, A.; Brbaklić, L.; Stanisavljević, D.; Ćeran, M.; Trkulja, D.; Mitrović, B. Molecular and phenotypic characterisation of diverse temperate maize inbred lines in Southeast Europe. Zemdirb. Agric. 2017, 104, 31-40. [CrossRef]

17. Sarca, T.R.; Chapter, X. Maize-Monographic Study; Romanian Academy: Bucharest, Romania, 2004; pp. $345-450$.

18. Halsey, M.E.; Remund, K.M.; Davis, C.A.; Qualls, P.J.; Eppard, P.J.; Berberich, S.A. Isolation of maize from pollen-mediated gene flow by time and distance. Crop Sci. 2005, 45, 2172-2185. [CrossRef]

19. Has, I. Crops Seed Production; AcademicPres: Cluj-Napoca, Romania, 2006.

20. Jugenheimer, R.W. Hybrid Maize Breeding and Seed Production; FAO: Rome, Italy, 1958.

21. Hallauer, A.R. Methods used in developing maize inbreds. Maydica 1990, 35, 1-16.

22. Brubaker, J.R.; Krutz, G.W.; Gibson, H.G.; Ukrainetz, P.R.; Nine, P.L. Hydraulic control system for a corn detasseler. SAE Trans. 1991, 100, 226-238.

23. Moreira, J.N.; Silva, P.S.L.; Silva, K.M.; Dombroski, J.L.; Castro, R.S. Effect of detasseling on baby corn, green ear and grain yield of two maize hybrids. Hortic. Bras 2010, 28, 406-411. [CrossRef]

24. Climate of the World: Romania. Available online: https://www.weatheronline.co.uk/reports/climate/Romania. htm (accessed on 1 January 2020).

25. Tinca, E. Studiul prolificității la porumbul timpuriu. Ph.D. Thesis, University of Agricultural Sciences and Veterinary Medicine of Cluj-Napoca, Cluj-Napoca, Romania, 2017.

26. Sarca, V. Chapter XI. In Maize-Monographic Study; Romanian Academy: Bucharest, Romania, 2004; pp. 463-510.

27. Butts-Wilmsmeyer, C.J.; Seebauer, J.R.; Singleton, L.; Below, F.E. Weather during key growth stages explains grain quality and yield of maize. Agronomy 2019, 9, 16. [CrossRef]

28. Tokatlidis, I.S. Adapting maize crop to climate change. Agron. Sustain. Dev. 2013, 33, 63-79. [CrossRef]

29. Czepak, M.P.; Kliemann, M.; Schmildt, O.; Araujo, R.N.; de Souza Oliveira, V.; Junior, L.M.B.; Zanala, A.G.B.; dos Santos, K.T.H.; Santos, J.S.H.; Santos, G.P.; et al. Effect of artificial detasseling and defoliation on maize seed production. IJPSS 2019, 28, 1-9. [CrossRef]

30. De Toledo Alvim, K.R.; de Brito, C.H.; Brandao, A.M.; Gomes, L.S.; Lopes, M.T.G. Quantification of leaf area and defoliation effect in corn crop components. Cienc. Rural 2010, 40, 1017-1022. [CrossRef]

31. Magalhães, P.C.; Durães, F.O.M.; de Oliveira, A.C.; Gama, E.E.G. Effects of different detasseling practices on maize yields. Sci. Agr. 1999, 56, 77-82. [CrossRef]

32. Komatuda, A.S.; Santos, C.M.D.; Santana, D.G.D.; Souza, M.A.D.; Brito, C.H.D. Effects detasseling methodologies on yield and quality of hybrid seed. Rev. Bras. Milho Sorgo 2006, 5, 359. [CrossRef]

33. Mafouasson, H.N.A.; Gracen, V.; Yeboah, M.A.; Ntsomboh-Ntsefong, G.; Tandzi, L.N.; Mutengwa, C.S. Genotype-by-environment interaction and yield stability of maize single cross hybrids developed from tropical inbred lines. Agronomy 2018, 8, 62. [CrossRef]

34. Sun, J.-Y.; Gao, J.-L.; Yu, X.-F.; Liu, J.; Su, Z.-J.; Feng, Y.; Wang, D. Combining ability of sixteen USA maize inbred lines and their outbreeding prospects in China. Agronomy 2018, 8, 281. [CrossRef]

35. Yang, L.; Jiang, T.; Fountain, J.C.; Scully, B.T.; Lee, R.D.; Kemerait, R.C.; Chen, S.; Guo, B. Protein profiles reveal diverse responsive signaling pathways in kernels of two maize inbred lines with contrasting drought sensitivity. Int. J. Mol. Sci. 2014, 15, 18892-18918. [CrossRef] [PubMed]

36. Wang, X.; Zenda, T.; Liu, S.; Liu, G.; Jin, H.; Dai, L.; Dong, A.; Yang, Y.; Duan, H. Comparative proteomics and physiological analyses reveal important maize filling-kernel drought-responsive genes and metabolic pathways. Int. J. Mol. Sci. 2019, 20, 3743. [CrossRef] [PubMed] 
37. Gong, F.; Wu, X.; Zhang, H.; Chen, Y.; Wang, W. Making better maize plants for sustainable grain production in a changing climate. Front. Plant Sci. 2015, 6, 835. [CrossRef] [PubMed]

38. Zenda, T.; Liu, S.; Wang, X.; Liu, G.; Jin, H.; Dong, A.; Yang, Y.; Duan, H. Key maize drought-responsive genes and pathways revealed by comparative transcriptome and physiological analyses of contrasting inbred lines. Int. J. Mol. Sci. 2019, 20, 1268. [CrossRef]

(C) 2020 by the authors. Licensee MDPI, Basel, Switzerland. This article is an open access article distributed under the terms and conditions of the Creative Commons Attribution (CC BY) license (http://creativecommons.org/licenses/by/4.0/). 